\title{
Sprawozdanie z XXV Zjazdu Polskiego Towarzystwa Historii Nauk Medycznych, Poznań, 10-11 października 2019 r.
}

W dniach 10-11 października 2019 r. w Centrum Kongresowo-Dydaktycznym Uniwersytetu Medycznego w Poznaniu odbył się XXV Zjazd Polskiego Towarzystwa Nauk Medycznych kontynuującego tradycje Polskiego Towarzystwa Historii Medycyny i Farmacji. Organizatorem Zjazdu była Katedra i Zakład Historii i Filozofii Nauk Medycznych Uniwersytetu Medycznego im. Karola Marcinkowskiego w Poznaniu.

Patronat honorowy nad Zjazdem objął Jego Magnificencja Rektor Uniwersytetu Medycznego w Poznaniu prof. dr hab. Andrzej Tykarski. Ponadto w skład Honorowego Komitetu Naukowego weszły osoby: dr hab. Jadwiga Brzezińska, prof. dr hab. Henryk Gaertner, prof. dr hab. Zdzisław Gajda, prof. dr hab. Antoni Jonecko, prof. dr hab. Andrzej Kierzek, dr hab. Aleksandra Kładna, prof. dr hab. Barbara Kuźnicka, prof. dr hab. Zyta Płotkowiak, prof. dr hab. Andrzej Śródka, prof. dr hab. Jerzy Supady, prof. dr hab. Edward Towpik, prof. dr hab. Ewa Wender-Ożegowska oraz prof. dr hab. Jacek Wysocki.

Komitet Naukowy, któremu przewodniczyła prof. Anita Magowska, tworzyli przedstawiciele różnych ośrodków naukowych: dr hab. Jarosław Barański, dr hab. prof. UŁ Aneta Bołdyrew, dr Maria Ciesielska, prof. dr hab. Andrzej Felchner, prof. dr hab. Ryszard Gryglewski, prof. dr hab. Jaromir Jeszke, dr hab. Walentyna Korpalska, dr hab. Anna Marek, prof. dr hab. Mariusz Migała, dr hab. Magdalena Paciorek, prof. dr hab. Bożena Płonka-Syroka, dr hab. Adam Szarszewski, prof. nadzw. dr hab. Beata Szczepańska, dr hab. Anna Trojanowska, prof. PAN oraz prof. dr hab. Bożena Urbanek.

Wśród ponad 50 uczestników Zjazdu znaleźli się badacze historii medycyny - historycy, lekarze, pielęgniarki, farmaceuci i reprezentanci innych zawodów medycznych oraz studenci - przedstawiciele wielu uniwersytetów, instytutów naukowo-badawczych Polskiej Akademii Nauk, niepublicznych oraz państwowych uczelni wyższych, muzeów, instytucji medycznych, towarzystw i stowarzyszeń z całego kraju. 
Wiodącym tematem obrad było Dziedzictwo przeszłości w medycynie wspótczesnej. Zjazd dedykowano pamięci Adama Wrzoska (1875-1965), inicjatora ruchu naukowego w zakresie historii i filozofii medycyny oraz nauk przyrodniczych w Polsce.

Uroczystego otwarcia XXV Jubileuszowego Zjazdu dokonała prof. dr. hab. Anita Magowska - przewodnicząca Polskiego Stowarzyszenia Historii Nauk Medycznych. W swoim wystąpieniu podkreśliła, że „wiedza o przeszłości jest kluczem do rozumienia współczesnej medycyny".

W pierwszej części wygłoszono trzy wykłady plenarne. Profesor Jan Barciszewski z Instytutu Chemii Bioorganicznej z Polskiej Akademii Nauk opisał Poczatki molekularnych nauk o życiu. Przybliżył badaczy tej problematyki, do których należeli m.in.: Richard Altman (1852-1900, urodzony w Iławie), Rudolf Singer (1903-1990), Michael Sela (ur. 1924 r. w Tomaszowie Mazowieckim jako Mieczysław Salomonowicz) czy Gḿter Blobel - laureat nagrody Nobla. Pozwoliło to przebyć drogę od odkrycia kwasu nukleinowego aż do epigenetyki. Podwójna helisa stanowiąca podstawowy element struktury przestrzennej cząsteczki DNA towarzyszyła jako model podczas obrad Zjazdu. Profesor dr hab. Grzegorz Raubo z Instytutu Filologii Polskiej Uniwersytetu Adama Mickiewicza wygłosił wykład pt. Literatura dawna w kontekstach historii medycyny. Doktor hab. Katarzyna Taborowska-Kaszuba z Katedry Kompozycji Akademii Muzycznej im. Ignacego Jana Paderewskiego zainteresowała uczestników wystąpieniem pt. Choroba jako inspiracja muzyki. Jak wynika z badań i obserwacji, dźwięki o określonej częstotliwości mogą okazać się terapeutyczne i aplikowane są jako tzw. dosery - „tabletki” w postaci fal dźwiękowych. Trzy, jakże odmienne w swej treści wykłady ukazały historię jako pomost łączący przeszłość z teraźniejszością i inspiracją dla przyszłości, co było myślą przewodnią Zjazdu.

Sesje naukowe odbywały się jednocześnie. W pierwszej prelegenci skupili się na zagadnieniach dotyczących medycyny społecznej (sesja pt. W kregu medycyny społecznej). Michał Musielak z Uniwersytetu Medycznego im. Karola Marcinkowskiego w Poznaniu podjął próbę odpowiedzi na pytania dotyczące udziału lekarzy w projektach eugenicznych oraz ich wpływu na środowisko medyczne. Opierając się na własnych badaniach dotyczących zaangażowania lekarzy w eksperymenty medyczne przedstawił ich konsekwencje etyczne i społeczne. Jarosław Barański - reprezentujący Uniwersytet Medyczny we Wrocławiu - wprowadził odbiorców w problematykę odkrycia Ignaca 
Semmelweisa będącego rezultatem splotu wyobrażeń, które ukierunkowały obserwację i przyczyniły się do odnalezienia przyczyny gorączki połogowej. Przedstawicielki Uniwersytetu Łódzkiego - Aneta Bołdyrew i Małgorzata Krakowiak - podjęły problem spożywania alkoholu przez dzieci i młodzież w Królestwie Polskim i na Kresach na początku XX w. Na łamach ówczesnej publicystyki naukowej i społecznej toczyła się dyskusja, która była, jak stwierdziły autorki, „przejawem medykalizacji i higienizacji problemów adolescencji” i nawiązywała do debat prowadzonych w Europie Zachodniej. Beata Szczepańska z tego samego Uniwersytetu przedstawiła sylwetkę czołowego działacza łódzkiego na rzecz zdrowia publicznego - lekarza pediatry dr. Stanisława Gutentaga. Poza pracą zawodową podejmował on również działalność w agendach opieki społecznej oraz instytucjach oświatowych, mierząc się z problemami okresu międzywojennego. Kolejny prelegent - Michał Chlipała z Collegium Medicum Uniwersytetu Jagiellońskiego zwrócił uwagę na znaczenie medycyny w wyszkoleniu Policji Państwowej w II Rzeczypospolitej. Konieczność posiadania wiedzy medycznej wynikała z zadań zawodowych, takich jak np. udzielanie pomocy ofiarom przestępstw i wypadków, sprawdzanie stanu sanitarnego czy zabezpieczanie śladów biologicznych.

Prowadzący, dr hab. Anna Elżbieta Trojanowska, prof. PAN, i prof. Anita Magowska zachęciły uczestników do dyskusji, która potwierdziła znaczenie dokonań przeszłości dla teraźniejszości i przyszłości medycyny i zdrowia publicznego.

Druga sesja, której przewodniczyli prof. Bożena Płonka-Syroka i dr Michał M. Skoczylas, obejmowała problematykę Medycyny $w$ okresie przedklinicznym. Aneta Liwerska z Collegium Medicum Uniwersytetu im. Adama Mickiewicza w Poznaniu przybliżyła postać starożytnego lekarza Asklepiadesa, który zaadaptował do medycyny atomistyczną teorię wszechświata, postrzeganą przez współczesnych badaczy jako zaczątek medycyny molekularnej. Monika Zamachowska (CM Uniwersytetu Jagiellońskiego) w wystąpieniu pod intrygującym tytułem Między cudownościq a nauka przedstawiła nietypowe przypadki medyczne podczas wypraw na Wschód opisane w tekstach podróżniczych, podejmując próbę sklasyfikowania chorób według współczesnej wiedzy. Prelegenci z Gdańskiego Uniwersytetu Medycznego - Bartłomiej Siek oraz Piotr Paluchowski - w referacie pt. Obieg wiedzy naukowej w zakresie anatomii na przykładzie rozpraw uczniów Gdańskiego Gimnazjum Akademickiego dokonali analizy materiału badawczego na przełomie XVII i XVIII w., z której wynika- 
ło, że dzieła anatomiczne w nowożytnym Gdańsku cieszyły się zainteresowaniem środowiska medycznego. Katarzyna Pękacka-Falkowska z Uniwersytetu Medycznego w Poznaniu kontynuowała podjęty temat, koncentrując swoje wystąpienie na działalności badawczej i wydawniczej gdańskich anatomów i zootomów - Gottwalda, Goedtkego i Heysego w drugiej połowie XVII w. Dociekała, jaki wpływ na ich badania mogły mieć pobyty studyjne na uniwersytetach niderlandzkich, gdzie mieli możliwość zapoznać się z Anatomia Nova. Wystąpienie Joanny Nieznanowskiej z Pomorskiego Uniwersytetu Medycznego również dotyczyło anatomii. Autorka przedstawiła nauczanie anatomii w ówczesnych szczecińskich szkołach - Pedagogium Książęcym, Gimnazjum Karolińskim i Królewskim Gimnazjum Akademickim w odniesieniu do programu nauczania i warunków, w jakich się odbywało. Jakub Węglorz (Uniwersytet Wrocławski) snuł refleksję nad złożonością doktryny humoralnej, zadając prowokacyjne pytanie, czy jest ona błędna, czy należy ją postrzegać jako utracone dziedzictwo?

Po zakończeniu sesji odbył się panel, który dotyczył pytań o teraźniejszość i przyszłość historii nauk medycznych w Polsce. Prowadzący - dr Katarzyna Pękacka-Falkowska, dr hab. Anna Trojanowska, dr Krzysztof Królikowski oraz prof. Anita Magowska - zainicjowali dyskusję na następujące tematy: potrzebę posiadania tematycznego czasopisma dla historyków medycyny, przyszłości historii farmacji i muzeów medycyny w Polsce, które znajdują się poza uczelniami oraz zasadności reprezentacji środowiska historyków medycyny, farmacji i nauk pokrewnych. Głos w dyskusji dotyczący czasopisma „Medycyna Nowożytna” zabrali m.in.: prof. Bożena Płonka-Syroka, prof. dr hab. Jaromir Jeszke oraz dr hab. Magdalena Paciorek.

Pierwszy dzień Zjazdu zwieńczyło walne zebranie uczestników.

W drugim dniu zjazdu sesje naukowe również odbywały się paralelnie. Tematem wiodącym pierwszej z nich były Lekarskie teorie i praktyka. Sesji przewodniczyła dr Maria Ciesielska i prof. Ryszard W. Gryglewski. W pierwszym wystąpieniu Mariusz Migała (Politechnika Opolska) i Beata Skolik (Specjalistyczny Szpital MSWiA w Głuchołazach) przedstawili początki rehabilitacji w Polsce i wkład ośrodka warszawskiego w rozwój gimnastyki leczniczej i upowszechnianie jej w ortopedii, reumatologii, w medycynie sportu, chirurgii i internie. Ośrodek powstał w 1929 r. z połączenia Centralnej Szkoły Wojskowej Gimnastyki i Sportów oraz Państwowego Instytutu Wychowania Fizycznego, a w 1938 r. został przekształcony w Akademię Wychowania Fizycznego. Jacek Halasz z Gdańskiego Uniwersytetu Medycznego 
podjął się krytyki teorii specyficznej etiologii chorób oraz mechanistycznej koncepcji choroby i paradygmatu biomedycznego w ujęciu T. Kielanowskiego - lekarza ftyzjatry, społecznika i filozofa medycyny, który odrzucał redukcjonistyczne podejście w medycynie $\mathrm{XX}$ w. na rzecz modelu biopsychospołecznego. Interesującą tematykę podjęła również Katarzyna Szmigiero (Uniwersytet Jana Kochanowskiego w Kielcach, Filia w Piotrkowie Trybunalskim), która zaprezentowała referat na temat depresji, określanej w świecie anglosaskim jako „czarny pies”. Taka personifikacja depresji, zdaniem autorki, mogła mieć poważne konsekwencje w sposobie percepcji i odbieraniu tej choroby przez pacjentów. Michał K. Owecki z Uniwersytetu Medycznego w Poznaniu przybliżył obraz padaczki przedstawiany na łamach „Przeglądu Lekarskiego” w latach 1862-1910, wskazując na aktualność ogólnych zasad leczenia profilaktycznego. Istotnym zagadnieniem badawczym była próba znalezienia miejsca evidence based medicine (EBM) w historii medycyny, biorąc pod uwage poprzedzające ją dokonania naukowe i stosowanie ich w praktyce klinicznej, które zaprezentował Ryszard Witold Gryglewski (CM Uniwersytetu Jagiellońskiego). Michał M. Skoczylas z Pomorskiego Uniwersytetu Medycznego dokonał przeglądu prac doktorskich na temat rzadkich chorób na przykładzie uniwersytetów w Kopenhadze, Reykjaviku i Rostocku. Analiza wykazała, że odgrywają one istotną rolę w poznawaniu problematyki tych chorób.

W sesji równoległej, której przewodniczyły dr Magdalena Grassmann i dr Monika Zamachowska, zajmowano się dziejami pielęgniarstwa i geriatrii. Izabela Spielvogel (Politechnika Opolska) przedstawiła zaangażowanie Żydówek w rozwój opieki medycznej na Śląsku na początku XX w. na przykładzie Żydowskiego Związku Kobiet funkcjonującego we Wrocławiu. Anna Marek zaś przybliżyła szeroką działalność pielęgniarek zakonnych w Powstaniu Warszawskim, które nie tylko tworzyły szpitale, brały udział w zabiegach operacyjnych i opiekowały się rannymi, ale także otaczały opieką ludność cywilną, pomagając $\mathrm{w}$ zaspokajaniu podstawowych potrzeb. Ukazania postaw środowisk medycznych podczas II wojny światowej i okupacji podjęli się Zbigniew i Krzysztof Kopocińscy (Kresowy Szpital Wojskowy z Przychodnią SPZOZ), którzy w tym celu posłużyli się przykładem sióstr Grzelińskich reprezentujących zawód lekarki i pielęgniarki. Mimo dramatycznych przeżyć, które były ich udziałem, nie utraciły powołania zawodowego, co plasuje je jako wzór dla następnych pokoleń. Magdalena Paciorek z Polskiej Akademii Nauk zaprezentowała obraz 
pielęgniarstwa polskiego lat 50., na który bezpośredni wpływ wywierała ówczesna polityka państwa polskiego. Zbyt mała liczba pielęgniarek wymuszała potrzebę wyszkolenia kadr w jak najkrótszym czasie. Powodowało to przypływ do zawodu tzw. młodszych pielęgniarek bez pełnych uprawnień, co obniżało jakość kadry i status zawodu. „Nowy Medyk" - dwutygodnik studencki okazał się platformą komunikacyjną, integracyjną oraz warsztatowo-szkoleniową, stanowiąc element subkultury studenckiej lat 80., o czym przekonywał Michał Początek (Prywatny Specjalistyczny Gabinet Neurologiczny). Natomiast Małgorzata Marcysiak (PWSZ w Ciechanowie) podjęła próbę ukazania przyczyn i dynamiki rozwoju opieki geriatrycznej w Polsce w realiach okresu powojennego $\mathrm{z}$ uwzględnieniem uwarunkowań demograficznych, epidemiologicznych i społecznych.

W kolejnej sesji pod przewodnictwem dr hab. Anny Marek i dr. Zbigniewa Kopocińskiego prezentowano Losy lekarzy polskich w XX wieku. Seweryna Konieczna z Gdańskiego Uniwersytetu Medycznego przedstawiła odkrycia polskich uczonych, m.in. A. Cieszyńskiego, J. Babińskiego, J. Brudzińskiego, J. Biernackiego czy M. Skłodowskiej-Curie, które wciąż kształtują współczesną medycynę. W referacie Medyczne drogi i bezdroża niedoszłego lekarza Józefa Pitsudskiego Zbigniew Girzyński (UMK w Toruniu) ukazał mało znane związki Marszałka z medycyną. Rozpoczął on studia medyczne po maturze, ale $\mathrm{z}$ powodów politycznych udało mu się ukończyć tylko pierwszy rok. Natomiast Krzysztof Królikowski (Stowarzyszenie d. Szpital Ujazdowski) przybliżył postać profesora Witolda Zawadowskiego, opierając się na materiałach archiwalnych oraz wspomnieniach syna. „Król Polskiej radiologii”, jak go nazywano, wniósł ogromny wkład w jej rozwój, ale był także nauczycielem wielu pokoleń radiologów. Kolejnym z przedstawianych lekarzy był Stanisław Nikodem Markiewicz, propagator idei kolonii dziecięcych w Polsce, o działalności którego opowiadał Krzysztof Prętki z Uniwersytetu Medycznego im. Karola Marcinkowskiego w Poznaniu. Następnie Michał Początek zaprezentował postacie oraz osiągnięcia dwóch szczecińskich profesorów - Bogusława Halikowskiego (1914-2004) i Zygmunta Machoya (1924-2018). Michał M. Skoczylas w kolejnym wystąpieniu omówił interesujące założenia Studiów nad twórczościa naukowa Doktora Władysława Biegańskiego, które były wynikiem prac Sekcji Metodologii Nauk Medycznych Polskiego Towarzystwa Lekarskiego w ostatnich dwóch latach. Wreszcie zespó1 Colegium Medicum Uniwersytetu Jagiellońskiego - Weronika Lebowa, 
Jerzy Król i Jan Bylica przedstawił dokonania wybitnego polskiego badacza w dziedzinie fizjologii Napoleona Nikodema Cybulskiego oraz jego rolę w odkryciu adrenaliny.

Jednoczasowo przebiegała sesja obejmująca Wybrane zagadnienia historii farmacji i medycyny, której przewodniczyli Joanna Nieznanowska i Michał Owecki. Rozpoczęła ją prof. Anita Magowska wystąpieniem Dziegieć jako lek w ujęciu historycznym, w którym przedstawiła, jak na przestrzeni wieków (od starożytności do połowy $\mathrm{XX}$ w.) zmieniały się poglądy na jego działanie lecznicze. Następnie Anna Trojanowska (PAN) dokonała przeglądu fotografii zamieszczanych na łamach „Wiadomości Farmaceutycznych” w okresie międzywojennym. Analiza dotyczyła ich rodzaju, roli, jaką pełniły, dynamiki zmian w badanym okresie oraz ich autorów. Gabriela Frischke (Muzeum Okręgowe im. Leona Wyczółkowskiego) i Wojciech Ślusarczyk (CM UMK) badali obecność tematyki dotyczącej broni chemicznej na łamach „Kroniki Farmaceutycznej”. Jak wynika z analizy, najczęściej znajdowała swoje miejsce w artykułach popularnonaukowych i popularyzatorskich, co miało charakter szkoleniowy dla szerszego grona odbiorców. Współpraca Wydziału Farmaceutycznego Akademii Medycznej im. Karola Marcinkowskiego w Poznaniu z przemysłem farmaceutycznym na przełomie wieków, bo od lat 50. aż do 2007 r., była tematem wystąpienia Piotra Skalskiego (Uniwersytet Medyczny w Poznaniu). Przejmującą problematykę Holokaustu podjęła Maria Ciesielska (Uczelnia Łazarskiego), która omówiła realizację Projektu Medical Review Auschwitz. Jego celem było udostępnienie światowej opinii publicznej unikatowych materiałów prezentujących badania naukowe medycyny okresu II wojny światowej, co pozwoliło na sformułowanie wniosków dla współczesnej medycyny i bioetyki. Roksana Wilczyńska (CM UMK) zaprezentowała historię farmacji na łamach „Biuletynu Informacyjnego” Pomorsko-Kujawskiej Okręgowej Izby Aptekarskiej w Bydgoszczy, a Szymon Urban (CM UJ) przedstawił historię początków medycyny kosmicznej.

Popołudniowe sesje skupiły uwagę słuchaczy nad nowym życiem oraz dziedzictwem dawnej medycyny.

Sesji $Z$ dziejów opieki medycznej nad nowym życiem przewodniczyła Katarzyna Szmigiero i Jarosław Barański (Anita Magowska). Pierwszy referat Anny Tatarkiewicz z Uniwersytetu Poznańskiego dotyczył niepłodności u mężczyzn w starożytnym Rzymie. Małgorzata Stawiak-Osocińska (Uniwersytet Jana Kochanowskiego w Kielcach) przedstawiła sylwetkę zasłużonego gdańskiego położnika, społeczni- 
ka i reformatora Franza Christiana Brunattiego na przełomie XVIII i XIX w. Urszula Kozłowska (Uniwersytet Szczeciński) zaprezentowała rozwijający się w tym samym czasie ruch na rzecz świadomego macierzyństwa na przykładzie działalności jego animatorki Justyny Budzińskiej-Tylickiej. Zwieńczeniem sesji było wystąpienie Marty Piszczatowskiej, która przybliżyła źródła in vitro w Polsce, przedstawiając pionierów białostockiego położnictwa i ginekologii.

Sesji dotyczącej dziedzictwa dawnej medycyny przewodniczyła Katarzyna Pękacka-Falkowska i Izabela Spielvogej. Już pierwsze wystąpienie Magdaleny Grassmann wzbudziło duże zainteresowanie, dotyczyło bowiem polskiego dziedzictwa medycznego w Stanach Zjednoczonych. Prelegentka zadała pytanie, czy zmierza ono ku rozwojowi, czy zapomnieniu.

Monika Grybel i Wojciech Ślusarczyk (CM UMK) podjęli próbę odpowiedzi na pytanie o charakter muzeów medycznych w Polsce. Posłużyła do tego ankieta dotycząca genezy, struktury organizacyjnej, pozyskiwania zbiorów i tworzenia ekspozycji. Zespół (Michał M. Skoczylas z Pomorskiego Uniwersytetu Medycznego w Szczecinie oraz Włodzimierz Szafiński i Grażyna Szafińska z PTTK w Żarnowie), reprezentowany przez pierwszego $\mathrm{z}$ autorów, przedstawił postacie i wydarzenia $\mathrm{z}$ historii medycyny $\mathrm{z}$ ośrodków lokalnych, m.in. Piotrkowa Trybunalskiego, Tomaszowa Mazowieckiego, Opoczna, które były zaangażowane $\mathrm{w}$ rozwój turystyki poznawczej. W ostatnim wystąpieniu kolejny zespół (Jerzy Król, Jan Bylica, Weronika Lebowa z CM Uniwersytetu Jagiellońskiego) przedstawił dziedzictwo Stanisława Bartolona Starszego, jednego z najsławniejszych medyków XVI w., który został wpisany na listę medyków królewskich przez Zygmunta Augusta. Nie tylko miał osiągniecia naukowe (wynalazł lek na kiłę), ale także, związany z Sandomierzem, był na tyle zaangażowany w życie społeczne tego miasta, że z własnych funduszy doprowadził do niego wodę przez akwedukt.

Sesje naukowe budziły duże zainteresowanie i zachęcały do dyskusji.

Podsumowanie zjazdu, którego dokonała prof. Anita Magowska, pozwoliło na wysunięcie zadowalających wniosków. Przede wszystkim, że nie brakuje entuzjastów historii. Uczestnicy byli w różnym wieku (nie zabrakło również studentów), wywodzili się z różnych ośrodków naukowych i badawczych, ale również z ośrodków klinicznych, co może świadczyć o poszukiwaniu inspiracji w przeszłości dla teraźniejszości i przyszłości. 